\title{
Ecological impact of transhumance on the trophic state of alpine lakes in Gran Paradiso National Park
}

\author{
R. Tiberti ${ }^{(1),(2), \star}$, M. Rogora ${ }^{(3)}$, G. Tartari(3), C. Callieri ${ }^{(3)}$ \\ Received April 14, 2014 \\ Revised September 18, 2014 \\ Accepted September 22, 2014
}

\section{ABSTRACT}

Key-words: livestock grazing, Gran Paradiso National Park, Alps, conservation measures
Transhumance - the summer transfer of livestock to highland pastures is a traditional practice in the European Alps and is considered an integral part of the mountain ecosystem. Mountain lakes are generally oligotrophic systems and are particularly sensitive to the nutrient input caused by livestock. The aim of the present study was to quantify the impact of livestock grazing on the trophic state of high-altitude lakes in an area where transhumance is a traditional practice (Gran Paradiso National Park, Western Italian Alps), taking into account its dual value of ecosystem component and potential threat to lakes' trophic status. The impact of flocks and herds grazing was estimated on sensitive parameters related to the trophic state of alpine lakes: water transparency, nutrient content, bacterial load and chlorophyll-a concentration. Transhumance produced a significant increase in the trophic state of lakes with high grazing pressure, but little or no effect was found at soft-impacted lakes. Even though heavy-impacted lakes represent a minority of the studied lakes (three out of twenty), we indicated conservation measures such as fencing, wastewater treatment and livestock exclosure to be tested in Gran Paradiso National Park.

\section{RÉSUMÉ}

L'impact écologique de la transhumance sur l'état trophique des lacs alpins dans le parc national du Grand Paradis

Mots-clés :
pâturage

du bétail,

Parc National du

Grand Paradis,

Alpes,

mesures de

conservation
La transhumance, transfert estival du bétail vers les pâturages d'altitude, est une pratique traditionnelle dans les Alpes européennes considérée comme une partie intégrante de l'écosystème de la montagne. Les lacs de montagne sont généralement des systèmes oligotrophes particulièrement sensibles à l'apport de nutriments causé par le bétail. Le but de la présente étude a été de quantifier l'impact du pâturage du bétail sur l'état trophique des lacs d'altitude dans une zone où la transhumance est une pratique traditionnelle (Parc National du Grand Paradis, ouest des Alpes italiennes), en tenant compte de sa double valeur de composante de l'écosystème et de menace potentielle pour l'état trophique des lacs. L'impact du pâturage des troupeaux a été estimé sur les paramètres sensibles liés à l'état trophique des lacs alpins : la transparence de l'eau, la teneur en éléments nutritifs, la charge bactérienne et la concentration en chlorophylle a. La transhumance produit une augmentation significative de l'état trophique des lacs où la pression de pâturage est forte, mais peu ou pas d'effet a été trouvé dans les lacs moins touchés. Même si les lacs très impactés représentent une minorité des lacs étudiés (trois sur vingt), nous avons indiqué les mesures de conservation telles que les clôtures, l'épuration des eaux usées et la mise en défens du bétail à tester dans le parc national du Grand Paradis.

(1) Alpine Wildlife Research Centre, Gran Paradiso National Park, Degioz 11, 1101 Valsavarenche, Aosta, Italy

(2) DSTA, Department of Earth and Environmental Sciences, University of Pavia, Via Ferrata 9, 27100 Pavia, Italy

(3) Institute of Ecosystem Study, National Research Council (CNR ISE), Largo Vittorio Tonolli 50, 28922 Verbania Pallanza, Italy

* Corresponding author: rocco.tiberti@gmail.com 


\section{INTRODUCTION}

Transhumance is the seasonal transfer of livestock from one grazing ground to another; in the alpine region, from lowland to highland pastures. Transhumance in the Alps dates back to 6000 years ago (Lichtenberger, 1994) and is still practiced in the whole region. Due to its long history, this traditional practice shaped much of the landscape in the Alps (Previtali, 2011). There is no memory of how the alpine landscape would appear without transhumance.

Currently, transhumance is considered an integral part of the ecosystem, and the progressive abandonment of this practice (Cernusca et al.,1999) is often viewed with concern for the likely negative consequences for alpine biodiversity due to land-use change (e.g. Laiolo et al., 2004; Herzog et al., 2005). This abandonment mostly affects the regions below the timberline, where pastures, in the absence of grazing, turn into shrub and forests. Under moderate grazing pressure, transhumance can improve the biodiversity of alpine vegetation (Bunce et al., 2004) and favor plant and animal species related to the open areas (Laiolo et al., 2004).

Mountain aquatic ecosystems are particularly sensitive to livestock presence in their watersheds, due to the small buffering capacity of the alpine vegetation and soils (Derlet et al., 2010). As a result, slight environmental pollution may have a significant impact on aquatic ecosystems since the biogeochemical processes (e.g. nutrient retention) are weak. Manure contains high amounts of nutrients which contribute to freshwater eutrophication (Belsky et al., 1999), and as a result an increase in bacterial and algal biomass (Derlet at al., 2012). In the Western United States, where cattle grazing in mountain areas has turned into a part of the landscape more recently than in Europe (since the 1850s), the effects of cattle on alpine water quality were recognized only after 30 years. As a consequence, some protected areas have been established (e.g. Yosemite National Park; Farquhar, 1965) to limit or prohibit livestock grazing in the upper part of the watersheds (Derlet et al., 2010). On the other hand, in many European mountain ranges, the same problems require different and challenging management measures, because of the need for maintaining transhumance to protect the "cultural landscape", which consists of a number of peculiar, unstable ecosystems maintained by the grazing action of livestock and by the traditional pastoral practices (Herzog et al., 2005).

To date, most of the studies on livestock impact in mountain aquatic habitats have been carried out in the United States (Derlet et al., 2008; Derlet et al., 2010; Myers and Kane, 2011; Derlet et al., 2012 ), typically approaching the issue from a public health perspective. The aim of the present study is to quantify the impact of livestock grazing on the water quality of high-altitude lakes from a conservation perspective, in an area where transhumance is an ancient, traditional practice, as in many regions of the Alps. To this purpose, the trophic state data collected in Gran Paradiso National Park (GPNP) within the framework of a monitoring campaign (2007-2013) which involved 20 high-altitude lakes affected by different levels of livestock grazing were used. The impact of livestock grazing was estimated on different parameters (water transparency, nutrient content, bacterial load and chlorophyll-a concentration) related to the trophic status of the lakes. This multi-parameter approach enabled us to check the consistency of the results obtained and to inter-compare the sensitiveness of each parameter. The results were discussed in the territorial context on a local and regional scale, with an attitude of respect for conservation. Indeed, the studied lakes are all included in a protected area, where the human activities should be conducted with full respect for natural ecosystems.

\section{MATERIALS AND METHODS}

\section{> STUDY AREA}

The GPNP (Western Italian Alps) is a protected area including all the 20 studied lakes virtually representing all the natural (non-dammed) lakes larger than one hectare in the protected area 


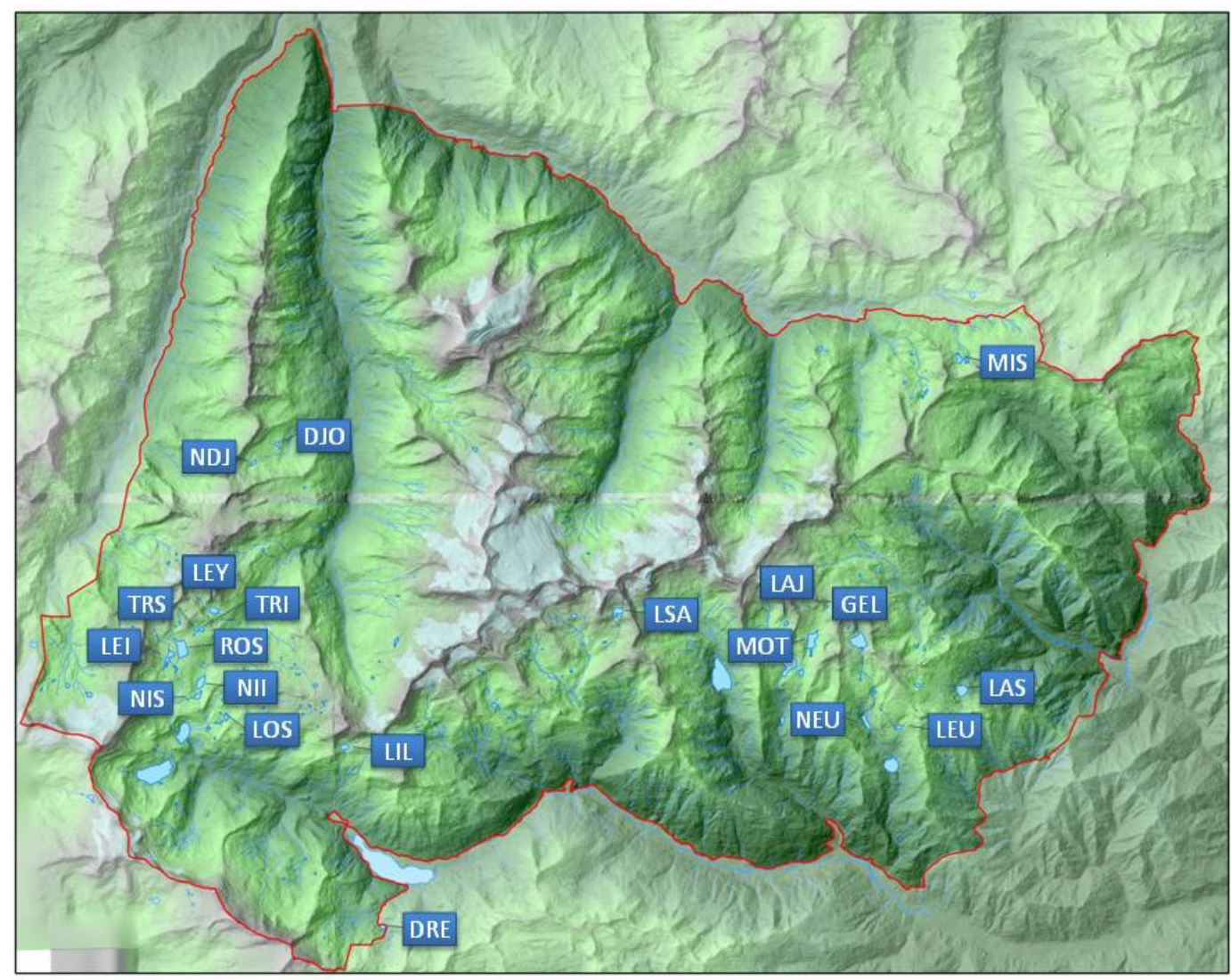

Figure 1

Map of the Gran Paradiso National Park and location of the studied lakes. Red line: park boundaries.

(Figure 1). The main characteristics and the acronyms of the lakes are summarized in Table I. The lakes are located above the local tree line (higher than $2000 \mathrm{~m}$ a.s.l.) with their watershed belonging to the alpine and nival belts. Human settlements in their catchments are absent. Due to the severity of the alpine climate the winter glacial cover lasts for 7-10 months per year. The trophic state ranges from ultra-oligotrophic to mesotrophic. In all the studied lakes, the in-water TN:TP molar ratio is always higher than 16 (range: 17-796), suggesting phosphorus limitation of the algal growth according to Redfield's ratio (Bergstrom, 2010).

\section{> THE ORGANIC POLLUTION INDEX (OPI)}

The magnitude of the pollution produced by livestock cannot be conveniently quantified, especially in natural, non-controlled conditions and over vast areas. Therefore, according to Derlet et al. (2012), the pressure exerted by the livestock on the areas surrounding the lakes was converted into a three-level categorical variable (Organic Pollution Index - OPI) depending on the intensity of grazing by cattle and ovine flocks in the lake catchment: pristine lakes with no livestock grazing (OPI: no), lakes with soft livestock grazing lasting for less than one month per summer (OPI: soft) and lakes with permanent summer livestock grazing in their catchments (OPI: heavy). Lakes NII, DRE and DJO were placed in the heavy category due to the presence of a large number of cattle and ovine flocks in the area surrounding and bordering the lakes (40-50 cattle in the DJO and NII areas and more than 1000 sheep in the DRE area). All the soft-impacted lakes are affected by a markedly lower grazing pressure, with cattle and ovine flocks just passing through these areas or staying for short periods. "Non-impacted lakes" are those without livestock. 
蛋

ชิ

อิธิ

¿

$0 \leqslant$

ذิ

ฝ) ह

र व

$\succ .0$

\begin{tabular}{|c|c|c|c|c|c|c|c|c|c|c|c|c|c|c|c|c|c|c|c|c|}
\hline 등 & $\times$ & $\times$ & & & & & & & $\times$ & $\times$ & $\times$ & $\times$ & & $\times$ & $\times$ & $x$ & $x$ & $\times$ & $\times$ & $\times$ \\
\hline ๓ా & $\times$ & $\times$ & & $\times$ & $\times$ & & & & $\times$ & $\times$ & $\times$ & $\times$ & $\times$ & $\times$ & $\times$ & $\times$ & $\times$ & $\times$ & $\times$ & $\times$ \\
\hline 초 & $\times$ & $\times$ & $\times$ & $\times$ & $\times$ & $\times$ & $\times$ & $\times$ & $\times$ & $\times$ & $\times$ & $\times$ & $\times$ & $\times$ & $\times$ & $\times$ & $\times$ & $\times$ & $\times$ & $\times$ \\
\hline 느 & & & & $\times$ & & & $\times$ & $\times$ & $\times$ & $\times$ & $\times$ & $\times$ & $\times$ & $\times$ & $\times$ & $\times$ & $\times$ & $\times$ & $\times$ & $\times$ \\
\hline$\overline{0}$ & ㅇ & 은 & ㅇ & 울 & 우 & 으 & ㅇ & 은 & $\begin{array}{l}\frac{\hbar}{0} \\
\infty\end{array}$ & $\begin{array}{l}\frac{\pi}{0} \\
\text { ↔ }\end{array}$ & $\begin{array}{l}\pi \\
0 \\
\infty\end{array}$ & $\begin{array}{l} \pm \\
0 \\
\infty\end{array}$ & $\begin{array}{l}\frac{\pi}{0} \\
\text { ஸ }\end{array}$ & $\begin{array}{l}\frac{\pi}{0} \\
\text { க }\end{array}$ & $\begin{array}{l}\frac{\hbar}{0} \\
\text { ळ }\end{array}$ & $\begin{array}{l} \pm \\
\infty \\
\infty\end{array}$ & $\begin{array}{l}\frac{\pi}{0} \\
\infty\end{array}$ & 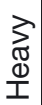 & 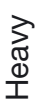 & 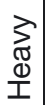 \\
\hline & & & & & & & & & & & & & & & & & & & & \\
\hline
\end{tabular}

बิ

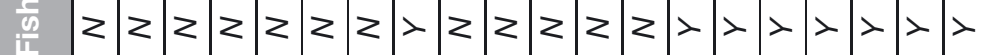

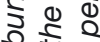

ชิ

을 흔

โ

娄

ర)

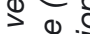

赵

T)

ชิ

का 0

$\frac{1}{2} \pi$ बृ

華兵

$$
z|z| z|z| z|z| z|z| z|z|>\mid z
$$

ह ठ

范 के

ঠ ণ্ণ

तु है

○े कृ

은 के

ह $\frac{0}{4}$ จ

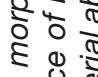

ن

ह ल

흐초

बें के

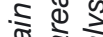

สิ ส ণิ

ह

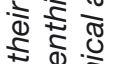

ज) ह

ह 이

๙ิ ฮ

잉 하

ปั ฮ

$\rightarrow$ 击

बळ

兵.

3 क ल

क. ㅇำ

สิ

0 인

बis

1) ฮ เ

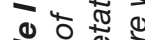

ำ ठ ฮ

O 4

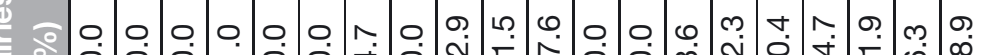
(.

क है

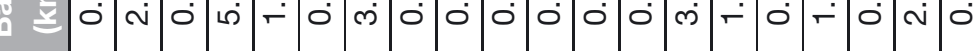

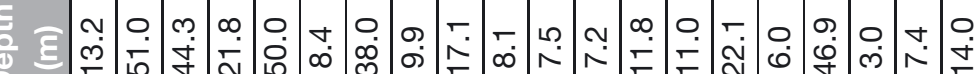

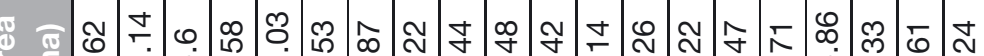

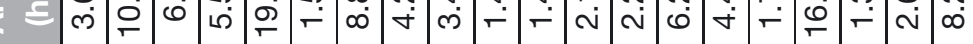

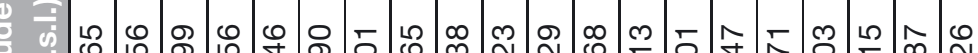

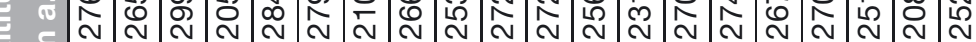

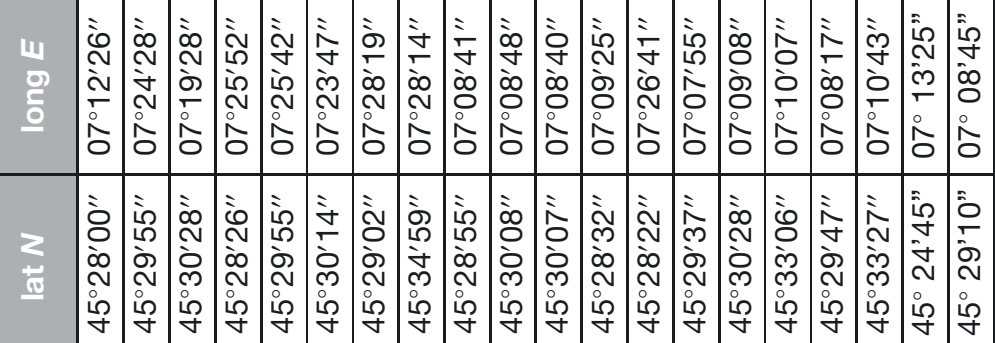

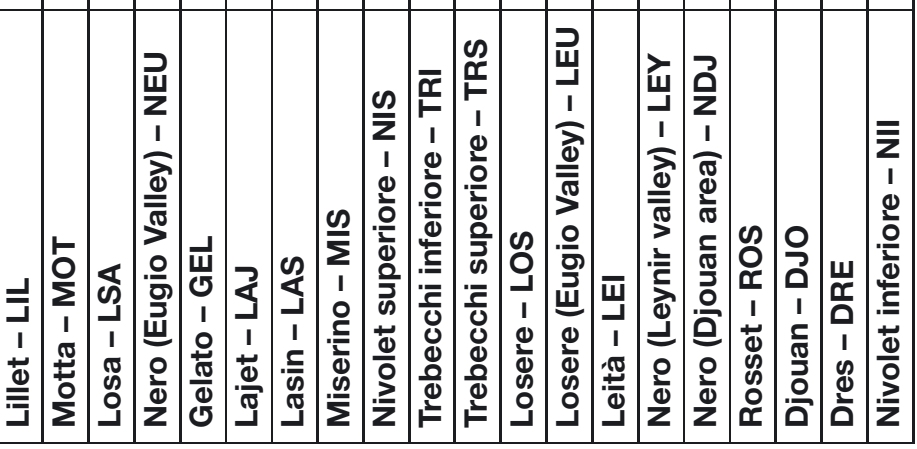




\section{Table II}

A summary of the monitoring campaigns of alpine lakes in the GPNP from 2007 to 2013. The numbers of samples/measurements and sampled lakes (in brackets) are reported.

\begin{tabular}{|l|c|c|c|c|c|c|c|c|}
\cline { 2 - 9 } \multicolumn{1}{c|}{} & 2007 & 2008 & 2009 & 2010 & 2011 & 2012 & 2013 & TOT \\
\hline $\begin{array}{l}\text { PAR profiles - } \\
\text { water transparency }\end{array}$ & - & - & - & $13(13)$ & - & $20(11)$ & $30(11)$ & $63(15)$ \\
\hline Chemical analyses & & $24(12)$ & $45(17)$ & $47(18)$ & $26(13)$ & $24(12)$ & $30(12)$ & $196(20)$ \\
\hline Bacteria & - & $71(12)$ & $72(6)$ & - & - & - & - & $143(16)$ \\
\hline $\begin{array}{l}\text { Chlorophyll-a } \\
\text { concentration }\end{array}$ & $22(11)$ & - & - & - & - & - & $30(12)$ & $52(13)$ \\
\hline
\end{tabular}

\section{> SAMPLING AND ANALYTICAL METHODS}

\section{Sampling history}

This study is based on data collected over the course of a monitoring campaign (2007-2013) involving a total of 20 lakes in the GPNP (Table I). In the succession of the years, some types of sampling/measurements were added and others were carried out in more limited periods. In Table II the entire sampling history is summarized. All the parameters were measured at different times of the ice-free period (usually two times, the first in June-July, the second in August-September) to take into account the strong seasonality governing alpine lakes (Tiberti et al., 2014). All the samplings and measurements were made from a dinghy at the deepest point of the lakes.

\section{Water transparency}

The vertical profiles of light intensity were measured throughout the water column at onemeter intervals, using a light meter (LI-COR LI-250) with a submersible sensor for Photosynthetically Active Radiation (PAR, 400-700 nm), from a few centimeters below the water surface to the bottom. The vertical extinction coefficient $(k)$ was estimated for each lake by fitting an exponential curve of the percent PAR reaching each sampling depth, assuming the mean of the surface measurements to be $100 \%$. The PAR profiles were measured in constant lighting conditions (full sunlight or persistent cloud cover without bright spells or drifting cloud patches).

\section{Nutrients}

Water samples $(500 \mathrm{~mL})$ were averaged over depth with a horizontal Van Dorn bottle, stored in the dark at $4{ }^{\circ} \mathrm{C}$, and analyzed at the laboratory of CNR ISE in Verbania Pallanza, Italy. Details on the analytical methods and the quality controls adopted in the laboratory can be found at: http://www.idrolab.ise.cnr.it/. Water samples were analyzed for conductivity (Radiometer ION450; APHA, 2005), $\mathrm{NH}_{4}^{+}$(UV-VIS spectrophotometry, spectrophotometer SAFAS UV mc ${ }^{2}$; Fresenius, 1988) and $\mathrm{NO}_{3}$ (ion chromatography after filtration on $0.8-\mu \mathrm{m}$ pore size filters: ion analyzer Dionex series DX320; APHA, 2005), total phosphorus (TP, UV-VIS spectrophotometry, spectrophotometer SAFAS UV mc2; Valderrama, 1981), total nitrogen (TN), and total organic carbon (TOC) (catalytic combustion with a Skalar Formacs series TOC/TN Analyzer; APHA, 2005). Organic nitrogen (ON) concentrations were calculated from the difference between $\mathrm{TN}$ and inorganic nitrogen $\left(\mathrm{IN}=\mathrm{NO}_{3}+\mathrm{NH}_{4}^{+}\right)$concentrations.

\section{Bacteria}

Samples for bacteria and picocyanobacteria analysis were collected at three different depths (at the surface, at mid-depth, and close to the bottom) with a horizontal Van Dorn bottle. Parallel to sampling, in situ measurements of temperature and oxygen profiles were performed 
using a multiparametric probe; Idroprobe IP145D (IDROMAR Srl., Genova, Italy). The samples were kept at low temperature in $200-\mathrm{mL}$ dark glass sterilized bottles and immediately fixed by adding filtered $(0.2 \mu \mathrm{m})$ formalin solution ( $2 \%$ final concentration). Two subsamples (0.5-1.0 mL) were stained with 4',6-diamidino-2-phenylindole (DAPI) staining (final concentration $0.1 \mu \mathrm{g} \cdot \mathrm{mL}^{-1}$ ) and filtered onto black polycarbonate membranes (Millipore, $0.22 \mu \mathrm{m}$ ) (Millipore, Billerica, MA, USA). DAPI-stained bacteria subsamples were enumerated under epifluorescence microscopy (filter set for Zeiss Axioplan - G 365/FT395 LP 420; Carl Zeiss, Oberkochen, Germany) and picocyanobacteria were distinguished and enumerated under blue excitation (filter set for Zeiss Axioplan-BP 450-490/FT 510/LP 520; Carl Zeiss). An image analysis software program (Image-Pro Plus 5.1; Media Cybernetics, Rockville, MD, USA) was used to estimate their mean cell volume $(75-518$ measurements per sample, mean $=166)$.

\section{Chlorophyll-a concentration}

Water samples for chlorophyll-a concentration measurements were averaged over depth with a horizontal Van Dorn bottle by mixing equal aliquots of water from different depths. Analytical methods were different in 2007 and 2013. In 2007 we applied a spectrofluorimetric method (APAT, 2003): 1.5-3 L of water was filtered through glass microfiber filters (Whatman GF/C, UK; pore size $0.7 \mu \mathrm{m}$ ) directly in the field; the filters were kept frozen at $-20{ }^{\circ} \mathrm{C}$ and analyzed in September at the laboratory of the Department of Earth, Environment and Life Sciences (DISTAV - University of Genova). In 2013 chlorophyll-a measurements were made directly on the samples collected for chemical analysis at the CNR ISE in Verbania, Pallanza, using a laboratory probe (FluoroProbe ${ }^{\mathrm{TM}}$, bbe-Moldaenke). According to Rolland et al. (2010), the FluoroProbe appears to be a reliable instrument suitable for comparisons with the measurements from the chlorophyll-a extraction and concentration method.

\section{> STATISTICAL ANALYSES}

The impact of livestock grazing (OPI) was estimated, accounting at the same time for other important ecological gradients: the altitudinal gradient (accounting for the altitudinal variations of climate and vegetation), the conductivity gradient (related to the ionic content and the watershed geology), the lakes' depth gradient (accounting for the different dimensions of the lakes), the seasonal gradient and, just in the case of stratified samples for bacteria, an in-lake depth gradient related to the sampling depth.

To take into account repeated samplings in the same lakes, generalized linear mixed models (glmm) with a Bayesian Markov chain Monte Carlo (MCMC) approach implemented in the R package MCMCglmm (Hadfield, 2010) were used for modeling the influence of a set of covariates on (1) the variability of water transparency, (2) the variability of the nutrient content in the water, including TP, $\mathrm{TN}, \mathrm{NH}_{4}^{+}, \mathrm{NO}_{3}^{-}, \mathrm{ON}$ and TOC, (3) the variability of bacterial density and size and the presence/absence of picocyanobacteria, and (4) the variability of chlorophylla concentrations.

The models were fitted choosing a set of relevant covariates and interactive effects, being careful not to insert correlated variables into the formula. An exhaustive summary of how the models were fitted is provided in Table III; the differences in the model structures are due to the different sampling methods (e.g. bacterial sampling) and, consequently, dataset properties. All the dependent variables were log-transformed to approximate normality and modeled following a Gaussian distribution, with the exception of picocyanobacteria presence/absence, which was modeled following a binomial distribution (MCMCglmm family = categorical). Three sampling dates with anomalous bacterial density at the bottom of the lakes were excluded from the dataset used in the analyses. The reasons for this exclusion are discussed in the "Discussion". All the statistical analyses were performed using R version 3.0.2 (R development core team, 2010). 


\section{Table III}

Generalized linear mixed models to determine the impact of transhumance on the trophic state of a set of alpine lakes: summary of their structures.

\begin{tabular}{|c|c|c|}
\hline Models & Model features & \\
\hline and nutrients & $\begin{array}{l}\text { Dependent variables } \\
\text { Fixed effects } \\
\text { Random effects } \\
\text { Error distribution }\end{array}$ & $\begin{array}{l}\log (k), \log _{10}(\mathrm{TP}), \log _{10}(\mathrm{TN}), \log _{10}\left(\mathrm{NH}_{4}^{+}+1\right), \log _{10}\left(\mathrm{NO}_{3}^{-}+1\right), \\
\log _{10}(\mathrm{TOC}+1) \\
\mathrm{D}_{\max }+\text { Alt }+\mathrm{C}+\text { Day } \times \text { OPI } \\
\text { Lake }+ \text { Year } \\
\text { Gaussian }\end{array}$ \\
\hline Bacterial density & $\begin{array}{l}\text { Dependent variables } \\
\text { Fixed effects } \\
\text { Random effects } \\
\text { Error distribution }\end{array}$ & $\begin{array}{l}\text { log (cell) } \\
\text { Depth }+ \text { Stratification }+\mathrm{T}+\mathrm{O} \%+\text { Alt }+\mathrm{C}+\text { Day } \times \text { OPI } \\
\text { Lake }+ \text { Year }+R 1 \\
\text { Gaussian }\end{array}$ \\
\hline Bacterial size & $\begin{array}{l}\text { Dependent variables } \\
\text { Fixed effects } \\
\text { Random effects } \\
\text { Error distribution }\end{array}$ & $\begin{array}{l}\text { log(bacterial size }) \\
\text { Depth } \times \text { Stratification }+\mathrm{T}+\mathrm{O} \%+\text { Alt }+\mathrm{C}+\text { Cell }+ \\
\text { Day } \times \text { OPI } \\
\text { Lake }+ \text { Year }+R 1+R 2 \\
\text { Gaussian }\end{array}$ \\
\hline Picocyanobacteria & $\begin{array}{l}\text { Dependent variables } \\
\text { Fixed effects } \\
\text { Random effects } \\
\text { Error distribution }\end{array}$ & $\begin{array}{l}\text { Picocyanobacteria presence/absence } \\
\text { Depth } \times \text { Stratification }+\mathrm{T}+\mathrm{O} \%+\mathrm{Alt}+\mathrm{C}+\mathrm{Cell}+ \\
\text { Day } \times \text { OPI } \\
\text { Lake }+ \text { Year }+R 1 \\
\text { Binomial }\end{array}$ \\
\hline Chlorophyll-a & $\begin{array}{l}\text { Dependent variables } \\
\text { Fixed effects } \\
\text { Random effects } \\
\text { Error distribution }\end{array}$ & $\begin{array}{l}\log (\text { chl-a }) \\
D_{\max }+\text { Alt }+ \text { Day } \times \text { OPI } \\
\text { Lake }+ \text { Year } \\
\text { Gaussian }\end{array}$ \\
\hline
\end{tabular}

"+": additive terms; "X": interactive terms; $D_{\max }$ : maximum depth (m); Alt: altitude (m a.s.I.); C: water conductivity $\left(\mu \mathrm{S} \cdot \mathrm{cm}^{-1}\right.$ at $\left.20{ }^{\circ} \mathrm{C}\right)$; Day: Julian date as days gone by June 15 of the year of sampling; OPI: Organic Pollution Index; Depth: sampling depth expressed as factorial variable with three levels (surface $-S$, mid-depth $-\mathrm{M}$ and deep $-D$ sampling); Stratification: binomial variable assuming value = 1 if a direct or inverse stratification was detected by the visual inspection of the temperature profiles and value $=0$ if no stratification was found; T: temperature at the sampling depth; O\%: percent oxygen concentration at the sampling depth; Lake: lake identity; Year: year of sampling; R1: random term encompassing the bacterial measurements at the three sampling depths; $R 2$ : random term encompassing all the biovolume measurements from the same sample.

\section{RESULTS}

\section{$>$ WATER TRANSPARENCY}

The PAR extinction coefficient ( $k$ ) ranges between 0.113 (lake LAS) and 0.656 (lake NII) (mean 0.265 , median 0.228; Table IV). Statistical models predict that $k$ is higher (lower water transparency) in heavy- than in non- and soft-impacted lakes, while the difference between nonand soft-impacted lakes is not significant (Table V, Figure 2). The interactive effect between the OPI and sampling date is significantly different in soft- and heavy-impacted lakes, meaning that kgrows faster in more polluted lakes. Also, the conductivity of water shows a significant negative effect on water transparency.

\section{> NUTRIENT CONCENTRATIONS}

Total phosphorus concentrations (range $1-20 \mu \mathrm{g} \cdot \mathrm{L}^{-1}$, mean $=3.8 \mu \mathrm{g} \cdot \mathrm{L}^{-1}$, median $=3.0 \mu \mathrm{g} \cdot \mathrm{L}^{-1}$ ) are higher in the lakes with a heavy impact than in the lakes with no or soft impact. 


\section{Table IV}

Parameters related to the trophic state of alpine lakes: average values $\pm S D$ for each Organic Pollution Index (OPI) category.

\begin{tabular}{|lc|c|c|c|}
\hline \multirow{2}{*}{ Variable } & \multicolumn{3}{|c|}{ OPI } \\
\cline { 3 - 5 } & $\boldsymbol{k}$ & No & Soft & Heavy \\
\hline TP & $\left(\mathrm{m} \mathrm{g} \mathrm{L}^{-1}\right)$ & $0.150 \pm 0.046$ & $0.225 \pm 0.053$ & $0.373 \pm 0.119$ \\
\hline $\mathrm{NO}_{3}$ & $\left(\mathrm{mg} \mathrm{L}^{-1}\right)$ & $0.248 \pm 0.053$ & $0.073 \pm 0.059$ & $0.099 \pm 0.093$ \\
\hline $\mathbf{N H}_{4}^{+}$ & $\left(\mu \mathrm{g} \mathrm{L}^{-1}\right)$ & $11.1 \pm 5.6$ & $16.6 \pm 19.39$ & $31.4 \pm 34.8$ \\
\hline $\mathbf{O N}$ & $\left(\mu \mathrm{g} \mathrm{L}^{-1}\right)$ & $37.2 \pm 42.1$ & $58.8 \pm 56.8$ & $104.2 \pm 60.0$ \\
\hline TN & $\left(\mathrm{mg} \mathrm{L}^{-1}\right)$ & $0.294 \pm 0.047$ & $0.148 \pm 0.078$ & $0.234 \pm 0.081$ \\
\hline TOC & $\left(\mathrm{mg} \mathrm{L}^{-1}\right)$ & $0.248 \pm 0.246$ & $0.501 \pm 0.761$ & $0.745 \pm 0.427$ \\
\hline Bacterial density & $\left(10^{3} \mathrm{cell} \mathrm{mL}^{-1}\right)$ & $746 \pm 416$ & $1030 \pm 516$ & $2072 \pm 1409$ \\
\hline Bacterial size & $\left(\mu \mathrm{m}^{3}\right)$ & $0.33 \pm 6.38$ & $0.17 \pm 0.69$ & $0.60 \pm 25.32$ \\
\hline Picocyanobacteria density & $\left(\mathrm{cell} \mathrm{mL}^{-1}\right)$ & $0 \pm 0$ & $1081 \pm 6818$ & $167 \pm 709$ \\
\hline Chl-a & $\left(\mathrm{mg} \mathrm{L}^{-1}\right)$ & $0.7 \pm 0.3$ & $0.5 \pm 0.5$ & $1.1 \pm 1.8$ \\
\hline
\end{tabular}

TP increases during the summer and the results from the interactive effect OPI $\times$ Day show that it increases faster in heavy- than in non- or soft- impacted lakes.

Total nitrogen (range 0.03-0.56 mg $\cdot \mathrm{L}^{-1}$, mean $=0.19 \mathrm{mg} \cdot \mathrm{L}^{-1}$, median $=0.17 \mathrm{mg} \cdot \mathrm{L}^{-1}$ ) shows very different dynamics related to livestock impact with lower values in soft-impacted lakes, but similar values in heavy- and non-impacted lakes. $\mathrm{NO}_{3}^{-}$(range 0-330 $\mu \mathrm{g} \cdot \mathrm{L}^{-1}$, mean = $105 \mu \mathrm{g} \cdot \mathrm{L}^{-1}$, median $\left.=69 \mu \mathrm{g} \cdot \mathrm{L}^{-1}\right)$, accounting for $62 \%$ of $\mathrm{TN}$, shows similar results, with higher values in non-impacted lakes. $\mathrm{NH}_{4}^{+}$(range $0-190 \mu \mathrm{g} \cdot \mathrm{L}^{-1}$, mean $=19 \mu \mathrm{g} \cdot \mathrm{L}^{-1}$, median $=$ $13 \mu \mathrm{g} \cdot \mathrm{L}^{-1}$ ) shows a non-significant tendency to follow the most usual scheme, with higher values in heavy-impacted lakes and similar values in soft- and non- impacted lakes. ON (range $0-367 \mu \mathrm{g} \cdot \mathrm{L}^{-1}$, mean $=64 \mu \mathrm{g} \cdot \mathrm{L}^{-1}$, median $=56 \mu \mathrm{g} \cdot \mathrm{L}^{-1}$ ) shows higher values in heavy- than in soft- and non-impacted lakes, and also higher values in soft- than in non-impacted lakes. The models predict a different seasonal trend in the case of TN dynamics, growing faster in heavyimpacted lakes than in soft-impacted lakes. TOC concentrations (range 0-6.9 mg. $\mathrm{L}^{-1}$, mean = $0.51 \mathrm{mg} \cdot \mathrm{L}^{-1}$, median $=0.40 \mathrm{mg} \cdot \mathrm{L}^{-1}$ ) are higher in heavy-impacted than in non-impacted lakes and grow faster in soft- and heavy- impacted lakes than in non-impacted lakes (Table V; Figure 2).

\section{$>$ BACTERIA}

Bacterial density ranges between $122 \times 10^{3}$ (11th September, 2009 at the surface in lake GEL) and $5814 \times 10^{3}$ bacteria per $\mathrm{mL}$ (30th June, 2008 at the bottom in lake NIS) (mean $1144.9 \times 10^{3}$, median $973 \times 10^{3}$; Table IV). Each outlier deviating from bacterial density distribution was considered separately to distinguish if it was generated by some ecological mechanism, not included in the following analyses. Outliers from 2 to 8 (numerated in Figure 3) were all generated by the normal seasonal dynamics in lakes belonging to the OPI category "heavy". Outlier 1 was instead produced at the bottom of lake NIS (June 30th, 2008) in an inverse stratification regime. During ice melting, similar, but lower, bacterial peaks were observed again at the lake bottom in NIS (8th July, 2009) and GEL (26th July, 2009). These peaks were always associated with oxygen depletion near the bottom and, in the case of NIS on the 8th July, 2009, also with a phosphorous peak. All the data from the samples collected in lakes with anomalous bacterial densities at the bottom, associated with oxygen depletion and inverse thermal stratification, were eliminated.

Statistical models predict that bacterial density is higher and increases faster in heavy- than in non- and soft-impacted lakes, while the difference between non- and soft-impacted lakes is not significant. The bacterial density also increases in relation to a seasonal gradient and a depth gradient, but only in non-mixed lakes (from which the significance of the interaction 


\section{Table $V$}

Results of MCMCgImm, relating the log-transformed PAR extinction coefficient ( $(k)$, the $\log _{10}$-transformed nutrient concentrations (TP, $\mathrm{TN}, \mathrm{NH}_{4}^{+}, \mathrm{NO}_{3}^{-}$, ON and TOC), and the log-transformed chlorophyll-a (Chl-a) concentration to the date of sampling (Day), the organic pollution index (OPI), the lake's depth, altitude, conductivity (C, fixed effect not included in Chl-a madel) and the interactive effect OPI x Day. The lake identity and the year of sampling were added as additive random effects. Models are based on $196 \mathrm{ob}-$ servations from 20 lakes.

\begin{tabular}{|c|c|c|c|c|c|c|c|c|c|}
\hline Mod & Fixed effects & & Mean & PMCMC & Mod & Fixed effects & & Mean & PMCMC \\
\hline \multirow{11}{*}{$\begin{array}{ll} \\
\end{array}$} & Intercept & & -4.515 & $<0.001$ & \begin{tabular}{|l|} 
TP \\
\end{tabular} & Intercept & & 1.510 & NS \\
\hline & Day & & 0.002 & NS & & Day & & 0.008 & $<0.001$ \\
\hline & OPI & soft vs. no & 0.236 & NS & & OPI & soft vs. no & 0.304 & NS \\
\hline & & no vs. heavy & -1.051 & $<0.05$ & & & no vs. heavy & -0.872 & $<0.05$ \\
\hline & & soft vs. heavy & -0.815 & $<0.001$ & & & soft vs. heavy & -0.568 & $<0.05$ \\
\hline & Depth & & -0.002 & NS & & Depth & & 0.005 & NS \\
\hline & Altitude & & 0.001 & NS & & Altitude & & 0.00 & NS \\
\hline & Conductivity & & -0.004 & $<0.01$ & & Conductivity & & -0.003 & NS \\
\hline & Day x OPI & soft vs. no & 0.004 & NS & & Day x OPI & soft vs. no & 0.004 & NS \\
\hline & & no vs. heavy & 0.006 & NS & & & no vs. heavy & -0.013 & $<0.001$ \\
\hline & & soft vs. heavy & -0.005 & $<0.05$ & & & soft vs. heavy & -0.009 & $<0.001$ \\
\hline \multirow[t]{11}{*}{ TN } & Interc & & $\mid-0.167$ & NS & $\mathrm{NO}_{3}$ & Intercept & & 2.852 & $<0.05$ \\
\hline & Day & & 0.00 & NS & & Day & & 0.008 & $<\mathbf{0 . 0 0 1}$ \\
\hline & OPI & soft vs. no & -0.398 & $<0.001$ & & OPI & soft vs. no & -0.866 & $<0.001$ \\
\hline & & no vs. heavy & 0.276 & $<0.05$ & & & no vs. heavy & 1.213 & $<0.001$ \\
\hline & & soft vs. heavy & -0.122 & NS & & & soft vs. heavy & 0.347 & NS \\
\hline & Depth & & 0.00 & NS & & Depth & & -0.003 & NS \\
\hline & Altitude & & 0.00 & NS & & Altitude & & -0.001 & NS \\
\hline & Conductivity & & 0.001 & NS & & Conductivity & & 0.003 & NS \\
\hline & Day x OPI & soft vs. no & -0.002 & NS & & Day x OPI & soft vs. no & -0.006 & $<0.05$ \\
\hline & & no vs. heavy & 0.00 & NS & & & no vs. heavy & 0.007 & $<0.01$ \\
\hline & & soft vs. heavy & -0.002 & $<0.1$ & & & soft vs. heavy & 0.001 & NS \\
\hline \multirow{11}{*}{$\mathrm{NH}_{4}^{+}$} & Interc & & 1.143 & $<0.1$ & ON & Interc & & 0.115 & NS \\
\hline & Day & & 0.001 & NS & & Day & & 0.003 & $<0.05$ \\
\hline & OPI & soft vs. no & 0.082 & NS & & OPI & soft vs. no & 0.490 & $<0.05$ \\
\hline & & no vs. heavy & -0.344 & $<0.1$ & & & no vs. heavy & $|-1.017|$ & $<0.001$ \\
\hline & & soft vs. heavy & -0.262 & $<0.1$ & & & soft vs. heavy & -0.527 & $<0.05$ \\
\hline & Depth & & -0.002 & NS & & Depth & & -0.001 & NS \\
\hline & Altitude & & 0.00 & NS & & Altitude & & 0.001 & NS \\
\hline & Conductivity & & -0.001 & NS & & Conductivity & & -0.003 & NS \\
\hline & Day x OPI & soft vs. no & -0.002 & NS & & Day x OPI & soft vs. no & 0.001 & NS \\
\hline & & no vs. heavy & 0.002 & NS & & & no vs. heavy & -0.002 & NS \\
\hline & & soft vs. heavy & 0.00 & NS & & & soft vs. heavy & -0.001 & NS \\
\hline \multirow{11}{*}{ TOC } & Intercept & & 0.310 & $\mathrm{NS}$ & Chl-a & Intercept & & -2.052 & NS \\
\hline & Day & & 0.001 & $<0.1$ & & Day & & 0.002 & NS \\
\hline & OPI & soft vs. no & 0.063 & NS & & OPI & soft vs. no & -0.078 & NS \\
\hline & & no vs. heavy & -0.134 & $<0.05$ & & & no vs. heavy & -0.744 & NS \\
\hline & & soft vs. heavy & -0.071 & NS & & & soft vs. heavy & -0.666 & NS \\
\hline & Depth & & 0.00 & NS & & Depth & & 0.010 & NS \\
\hline & Altitude & & 0.00 & NS & & Altitude & & 0.001 & NS \\
\hline & Conductivity & & 0.00 & NS & & & & & \\
\hline & Day x OPI & soft vs. no & -0.001 & NS & & Day x OPI & soft vs. no & 0.001 & NS \\
\hline & & no vs. heavy & -0.002 & $<0.05$ & & & no vs. heavy & 0.001 & NS \\
\hline & & soft vs. heavy & -0.001 & $<0.1$ & & & soft vs. heavy & 0.002 & NS \\
\hline
\end{tabular}



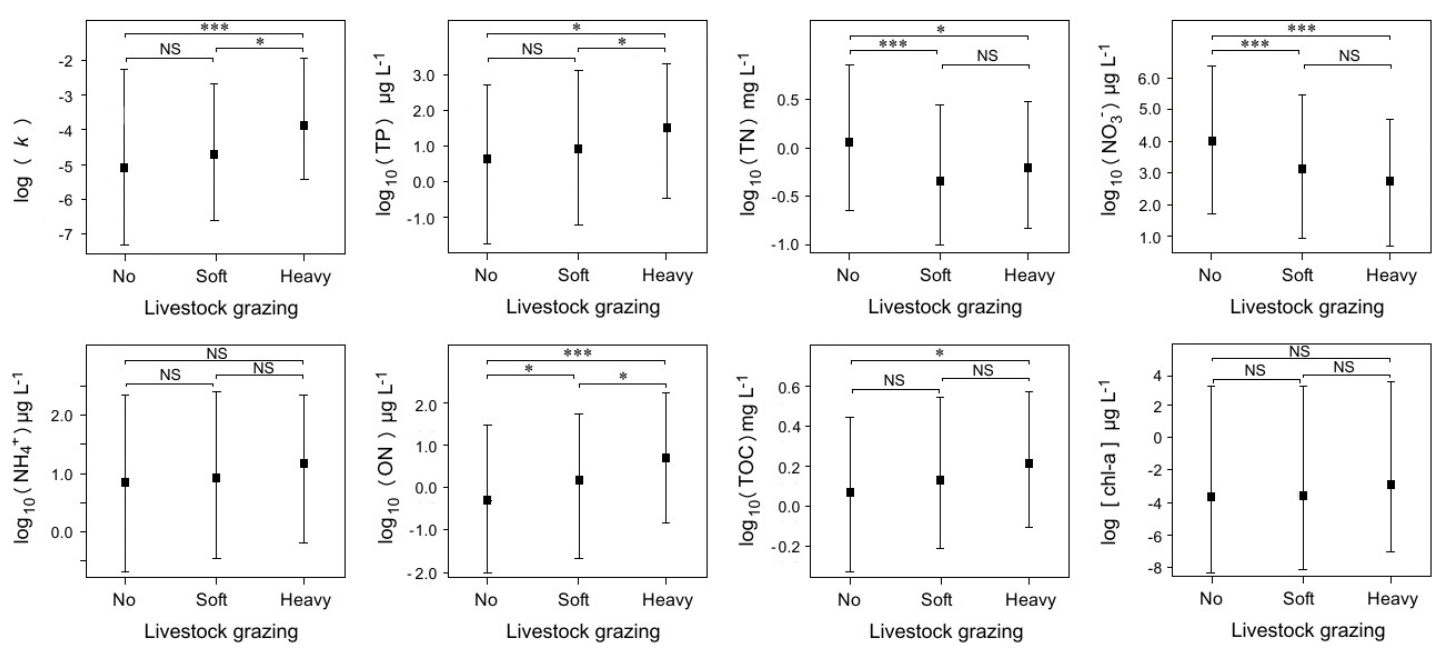

\section{Figure 2}

Post-mean estimates (black squares) and associated credibility intervals of the PAR extinction coefficient (k), the nutrient contents (TP, TN, $\mathrm{NH}_{4}^{+}, \mathrm{NO}_{3}, \mathrm{ON}$ and TOC) and the chlorophyll-a concentration (chl-a) under different livestock grazing pressures in the alpine lakes of the GPNP. Values fitted by the Markov chain Monte Carlo generalized linear mixed model (Table V).

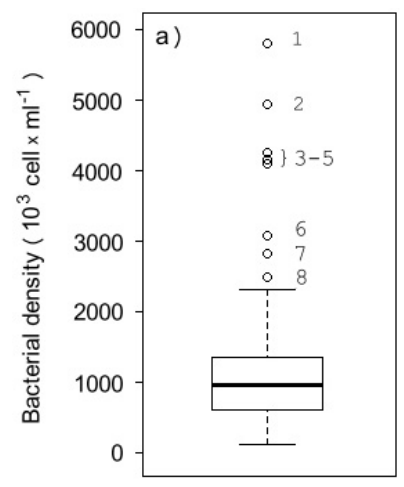

Figure 3

Panel (a): boxplot showing the bacterial density distribution. Panel (b): post-mean estimates and Cl intervals from different sampling dates from MCMCgImm (Table VI) showing the seasonal trend of the bacterial density in alpine lakes under no (blue, solid lines), soft (orange, dashed lines) and heavy (red, dotted lines) livestock grazing. Panel (c): boxplots comparing the differences of the distributions of the variances of the bacterial density calculated from the counts made at different depths of sampling in stratified and non-stratified lakes.

depth $\times$ stratification). A comparison of the distributions of the variances of the densities from the three different sampling depths in mixed and non-mixed lakes consistently shows that the variance is higher in stratified lakes $(t=27.3, p$-value $<0.0001$ ) (Figure 3; Table VI).

Picocyanobacteria were rare (not found in $79 \%$ of samples), and their maximum density was $61 \times 10^{3}$ cell $\mathrm{mL}^{-1}$ (August 3rd, 2009 at the bottom of lake NIS; Table IV). Variables related to the depth gradient (depth and stratification) are the only fixed terms whose influence on the presence of picocyanobacteria is significant (depth: $S$ vs. $P$ post-mean $=-74.5$, $\mathrm{pMCMC}<0.01$; M vs. P post-mean $=-88.6$, pMCMC $<0.001$; $\mathrm{S}$ vs. $\mathrm{M}$ post-mean $=-14.1$, $\mathrm{pMCMC}=\mathrm{NS}$; stratification: yes vs. no post-mean $=116.4$, pMCMC $<0.05)$, showing that picocyanobacteria can be more likely found at the bottom of alpine lakes, and especially when the lakes are stratified. Also, the cell size does not show a significant dependence on the OPI level, or on the other covariates. 


\section{Table VI}

Results of MCMCgImm, relating the log-transformed bacterial density to the date of sampling (Day), the organic pollution index (OPI), the sampling depth (depth), stratification (yes-no), temperature and percent oxygen concentration at the sampling depth and to the interactive effects between OPI and Day and between depth and stratification. The lake identity, the year of sampling and a grouping variable for taking into account the fact that lakes were sampled three times (at different depths) on each sampling date were added as random effects. Models are based on 143 observations from 16 lakes.

\begin{tabular}{|c|c|c|c|}
\hline Fixed effects & & Post-mean & pMCMC \\
\hline Intercept & & 5.517 & $<0.05$ \\
\hline Day & & 0.018 & $<0.01$ \\
\hline \multirow[t]{3}{*}{ OPI } & \multirow{3}{*}{$\begin{array}{l}\text { soft } v s . \text { no } \\
\text { no } v s \text {. heavy } \\
\text { soft } v s \text {. heavy }\end{array}$} & 0.401 & $<0.1$ \\
\hline & & -1.302 & $<0.001$ \\
\hline & & -0.901 & $<0.01$ \\
\hline \multirow[t]{3}{*}{ Depth } & \multirow{3}{*}{$\begin{array}{l}\text { S vs. D } \\
\text { M vs. D } \\
\text { M vs. S }\end{array}$} & -0.090 & NS \\
\hline & & -0.109 & NS \\
\hline & & 0.019 & NS \\
\hline Stratification & \multirow[t]{2}{*}{ yes vs. no } & 0.307 & NS \\
\hline Temperature & & $\begin{array}{l}-0.008 \\
\end{array}$ & NS \\
\hline \multicolumn{2}{|l|}{ Altitude } & 0.001 & NS \\
\hline \multicolumn{2}{|l|}{$\left[\mathrm{O}_{2}\right] \%$} & 0.004 & NS \\
\hline \multicolumn{2}{|l|}{ Conductivity } & -0.001 & NS \\
\hline \multirow[t]{3}{*}{ Day $\times$ OPI } & \multirow{3}{*}{$\begin{array}{l}\text { soft } v s . \text { no } \\
\text { no vs. heavy } \\
\text { soft vs. heavy }\end{array}$} & 0.005 & NS \\
\hline & & -0.019 & $<0.05$ \\
\hline & & -0.014 & $<0.05$ \\
\hline \multirow[t]{3}{*}{ Depth $\times$ Stratification } & \multirow{3}{*}{$\begin{array}{l}\text { S vs. D } \\
M \text { vs. D } \\
M \text { vs. S }\end{array}$} & -0.524 & $<0.001$ \\
\hline & & -0.345 & $<0.05$ \\
\hline & & 0.179 & NS \\
\hline
\end{tabular}

\section{$>$ CHLOROPHYLL-A}

Chlorophyll-a concentrations (range $0-5.18 \mu \mathrm{g} \cdot \mathrm{L}^{-1}$, mean $=0.636 \mu \mathrm{g} \cdot \mathrm{L}^{-1}$, median $=$ $0.305 \mu \mathrm{g} \cdot \mathrm{L}^{-1}$; Table IV) do not show any significant difference under different OPI levels. All the results are summarized in Table $\mathrm{V}$ and Figure 2.

\section{DISCUSSION}

\section{> GENERAL PATTERNS AND SENSITIVENESS OF THE PARAMETERS}

The results for most of the chosen parameters (transparency, TP, ON, TOC and bacterial density) are strongly consistent and the impact of transhumance followed a general coherent scheme, with significant differences between non- or soft-impacted lakes and heavyimpacted lakes and sometimes also between non- and soft-impacted lakes (ON). The response of this group of parameters shows that alpine lakes can sustain just a moderate livestock grazing pressure. Livestock presence can locally produce strong and visible effects, often obscuring some natural, well-documented gradients, such as the altitudinal trophic gradient. However, heavy-impacted lakes represent a minority of the studied lakes (three out of twenty). Therefore, the overall evaluation of the effect of livestock on mountain lakes should take into account that transhumance is a rather localized risk factor.

A second general pattern featuring the impact of transhumance is caused by seasonality. Transhumance is indeed a seasonal source of organic compounds, peaking in late summer, and the magnitude of its impact usually increases during the season, with an influence on water transparency, TP and TOC concentrations, and bacterial density.

Several parameters proved to be sensitive to the presence of livestock, with very similar and direct responses. A significant difference between non- and soft-impacted lakes was 
also detected in the response of ON, suggesting that small amounts of organic compounds can also produce detectable, even if lighter, effects. The sensitivity of other parameters was weaker: ammonium showed a non-significant tendency to respond to transhumance; TN and $\mathrm{NO}_{3}^{-}$, depended on different environmental gradients (nitrogen depositions and retention); the density of picocyanobacteria, the size of bacterial cells and chlorophyll-a concentration showed a non-significant dependence on the presence of livestock in their watersheds.

\section{>ECOLOGICAL IMPACT: PARAMETER BY PARAMETER}

Water transparency is usually high in mountain oligotrophic lakes not affected by glacial silt inputs but, according to the results of the present study, livestock grazing can affect water transparency and its natural seasonal pattern (in heavy-impacted lakes, turbidity increases during the summer). In the most serious cases, water transparency can drop to abnormally low levels (e.g. lake NII). The described changes in water transparency can directly depend on the input of organic matter, by the turbidity produced by livestock movements in the littoral area, or by algal blooms sustained by nutrient enrichment. Independently of the cause - or the interplay of causes - producing more turbid conditions, the ecological consequences are likely important. Indeed, water transparency, coupled with ultraviolet radiation (UVR, 290-400 nm), which is high at higher elevation, is a crucial abiotic factor shaping alpine lake biota (Sommaruga, 2001).

Nutrient enrichment in mountain lakes is considered the primary cause of most of the described impacts produced by transhumance (e.g. algal and bacterial blooms; Derlet et al., 2012). Nutrients can reach the lakes when the manure is left directly in the water, by the weathering action of rainwater on the manure left in the surrounding terrestrial habitats, by the percolate from stables and manure heaps, or by the resuspension of sediment due to cattle movement in the littoral area (Mosley et al., 1999). A significant increase in nutrients (TP, ON and TOC) was also observed in the heavy-impacted lakes of Gran Paradiso National Park. The increase in TP is particularly important, since phosphorus is the limiting factor for primary producers in these lakes, controlling the biomass of planktonic and benthic algae, aquatic vegetation, and bacteria. On the other hand, the concentrations of $\mathrm{TN}$ and $\mathrm{NO}_{3}$ are mainly related to nitrogen atmospheric deposition and are driven by the $\mathrm{NO}_{3}^{-}$dynamics (which accounts for $62.2 \%$ of the total nitrogen content), even if livestock is an additive source of nitrogen compounds (Ohio State University, 2006). In Northern Italy, nitrogen load due to atmospheric deposition can reach values as high as $15 \mathrm{~kg} \cdot \mathrm{ha}^{-1} \cdot \mathrm{y}^{-1}$ (Rogora et al., 2006), while in this study it was $14.4 \mathrm{~kg} \mathrm{~N} \cdot \mathrm{ha}^{-1} \cdot \mathrm{y}^{-1}$ (estimated value in 2009 at the sampling station of La Thuile, about $30 \mathrm{~km} \mathrm{NW}$ of the Gran Paradiso National Park; Tiberti et al., 2013). The TN concentration and the relative proportion of different nitrogen compounds are controlled both by atmospheric $N$ deposition rates, and by catchment features (Marchetto et al., 1994). In particular, the final concentration of $N$ in lakes is mediated by the retention process, and nitrogen retention capacity is higher in pastures than in alpine sparse vegetation. It is likely that higher nitrogen ( $\mathrm{TN}$ and $\mathrm{NO}_{3}$ ) concentrations in the lakes not affected by transhumance are produced by the low $N$ retention capacity of the rocky areas often surrounding these lakes, unsuitable for livestock grazing. The impact of livestock on the nitrogen cycle is instead visible looking at the response of $\mathrm{ON}$ and, to a lesser extent, at the tendency showed by $\mathrm{NH}_{4}^{+}$. Manure indeed contains high amounts of both ammonium and organic nitrogen (Ohio State University, 2006).

The bacterial density in GPNP lakes is consistent with what has been observed in other alpine lakes, but some very high values occasionally appeared in the present study. In Lake Paione superiore (Central Italian Alps), the range of bacterial abundance was $0.1-1 \times 10^{6} \mathrm{cells} \cdot \mathrm{mL}^{-1}$ (Callieri and Bertoni, 1999), in Jöri lake (Eastern Swiss Alps) $0.7-1.7 \times 10^{6}$ cells $\cdot \mathrm{mL}^{-1}$ (Hinder et al., 1999), and in Gossenköllesee (Tyrol, Austria) $0.25-0.55 \times 10^{6}$ cells $\mathrm{mL}^{-1}$ (Wille et al., 1999). In the present study the highest bacterial abundance $\left(>5 \times 10^{6} \mathrm{cells} \cdot \mathrm{mL}^{-1}\right.$, lake NIS) was measured near the lake bottom in association with oxygen depletion and the phosphorous peak. Alpine lakes can be naturally affected by anoxic conditions at the water-sediment 
interface during winter ice-cover and thaw (Ohlendorf et al., 2000). These anaerobic conditions may favor the release of phosphorus from the sediment, with the consequence of the rapid bacterial growth of groups, such as anaerobic ammonium-oxidizing (anammox) bacteria (Madigan et al., 2009). Alternatively, there could be an input of terrestrial bacteria transported into the lakes during thawing by melting water. The results show that the bacterial densities are significantly lower in non- or soft- than in heavy-impacted lakes and the OPI level produces different seasonal trends, with bacteria growing faster in heavy- than in non- or soft-impacted lakes. In stratified lakes bacterial abundance follows a vertical gradient, with the formation of stable ecological niches at different depths and the establishment of more numerous bacterial communities near the bottom. Autotrophic picocyanobacteria are rare in the studied alpine lakes and are more likely found at the bottom of stratified lakes, therefore they are not influenced by transhumance. Even if picocyanobacteria increase their relative abundance in oligotrophic lakes, their presence in alpine lakes is rare as they are sensitive to the high PAR and UV radiation affecting lakes with clear water at high elevation (Callieri et al. 2001). We expected that nutrient enrichment due to livestock grazing would have had an influence on bacterial size; conversely, no relation was found between transhumance and bacterial size. Likely the competition for nutrients in alpine lakes remains very strong and a greater nutrient availability results in an increase in the density rather than the mean cell volume of bacteria.

The results do not highlight a significant impact of transhumance on the concentration of chlorophyll-a. This could be partially due to the small sample size, but also to the lower sensitivity of chlorophyll-a to transhumance impact. In particular, also in the three lakes in the heavy OPI category, chlorophyll-a does not respond to nutrient enrichment (TP) due to livestock presence. Indeed, chlorophyll-a is a proxy of planktonic algal biomass, but the observed nutrient increase could have promoted not only phytoplankton, but also benthic algae and vegetation (Derlet et al., 2012), which compete with phytoplankton for nutrients (Hansson, 1992). For example, lake NII (OPI category: heavy; $14 \mathrm{~m}$ deep) presents high chlorophyll-a concentrations (mean: $4.21 ; N=3$ ), whereas lakes DJO and DRE (OPI category: heavy) contain rather small amounts of chlorophyll-a (mean (DJO): 0.20, $N=6$; mean (DRE): 0.09, $N=4$ ), similar to or lower than those found in pristine lakes (mean: $0.48 ; N=39$ ). Nevertheless, lakes DJO and DRE are shallow (3.0 and $7.4 \mathrm{~m}$ deep), and with an aquatic vegetation cover up to the bottom and along most of the littoral area, with thick, sometimes floating algal mats, likely outcompeting planktonic algae for nutrients. Chlorophyll-a concentration probably depends on the particular limnological characteristics of each of these three lakes and the presence of aquatic vegetation and benthic algae together with nutrients should be considered as an important factor regulating chlorophyll-a concentration (Hansson, 1992).

\section{> TRANSHUMANCE AND WATER QUALITY: A TRADITIONAL HAZARD}

Livestock grazing has huge ecological costs (Fleischner, 1994). The detrimental effects of livestock grazing are well documented (Belsky et al., 1999), as well as its impact on water quality (Derlet and Carlson, 2006). The present study adds a piece of information considering the effects of livestock on the water quality of alpine lakes, in a region where transhumance is an ancient practice, sustaining many valuable ecosystems.

The results show that transhumance may have conspicuous effects on the trophic state of alpine lakes, with possible bottom-up indirect ecological effects. Even if practiced for thousands of years, transhumance remains a source of organic compounds and an environmental risk factor. The results are similar to those obtained from North American mountain ranges, where most of the studies concerning livestock impact on mountain aquatic habitats have been carried out and where transhumance is a relatively recent farming practice (dating back to the late 19th century). These studies show that livestock grazing can increase the bacterial abundance (Derlet and Carlson, 2004; Derlet and Carlson, 2006; Derlet et al., 2008; Ursem et al., 2009; Myers et al., 2011; Derlet et al., 2012; Myers and Whited, 2012) and the benthic algal coverage (Derlet et al., 2012), and can produce significant changes in the algal 
(Derlet et al., 2012) and faunal diversity (del Rosario et al., 2002; Knapp and Matthews, 1996; Powers et al., 2011). Most of these studies have a public health perspective, usually using coliform bacteria as an indicator of organic pollution. Other indirect paleolimnological studies confirm that the observed ecological changes produced by livestock grazing have also occurred in the past centuries (e.g. Hausmann et al., 2002).

These parallels between ancient and recent transhumance areas do not exclude that the long coexistence between transhumance and wildlife could have produced a greater ecosystem resistance and some local adaptations in alpine biota, as an evolutionary/plastic response to the environmental pressure exerted by domestic animals. This topic should be addressed in more detail with a quantitative comparison of the biodiversity in aquatic, riparian and grazed habitats in ancient vs. recent transhumance areas. Whatever the relative resistance to livestock grazing of traditional and early transhumance areas, the present study highlights a critical and challenging aspect of transhumance. This aspect should be considered, with particular attention paid to the undesirable effects of a further abandonment of alpine pastures. The management practices designed in other countries to reduce the impact of livestock in mountain areas cannot be strictly applied to the alpine environment, both for conservation and socioeconomic reasons. The current debate in countries with an advanced level of conservation policies (e.g. the United States and Australia), is indeed focused on limiting livestock grazing at lower altitudes or prohibiting it in mountain areas, to preserve water resources (e.g. drinking water quality standard) and high-altitude habitats (Derlet et al., 2010). This debate may even become a conflict in some protected areas such as the Victoria Alpine National Park (Australia), where the decision to permit cattle grazing produced a clash between cattlemen's interests and conservation measures (Fraser and Chisholm, 2000). Alpine transhumance requires more complex solutions and management practices and a full collaboration between farmers and the institution for nature conservation.

\section{> CONSERVATION MEASURES}

To reduce the impact of livestock to a sustainable level one should take into account two apparently opposite conservation measures - maintain both transhumance and unpolluted habitats - by planning good transhumance practices with full respect for natural ecosystems. Livestock impact on alpine lakes is produced when (1) there are too many animals; (2) livestock have free access to the lakes and tributaries, and (3) nutrients reach the lakes from the terrestrial areas. All the actions aimed at limiting these risk factors can potentially reduce the impact of transhumance on alpine lakes.

A primary action is to reduce the number of animals in alpine pastures. This can directly produce a decrease in the released nutrient load and, over a longer period, restore overgrazed pastures, improving the nutrient retention processes in the catchment and in the lake itself, even if overgrazed pastures and lake self-purification can take many years to recover (Klein, 1987).

A second action is to prevent the livestock access to the lakes through exclusion fences (Sarr, 2002). This would prevent the manure from being left directly in the water or in the littoral areas. Exclusion fences require the installation of alternative watering points which can also attract livestock away from riparian zones (Smith et al., 1992) and reduce the time that cattle spend standing in the littoral areas (Miner et al., 1992; Mosley et al., 1999) and the inputs of pollutants (Sheffield et al., 1997). Alternative water sources should be far away from the surrounding manure heaps, and the watering points should be transportable or displaced in different sites to avoid large manure accumulation.

A third strategy consists of a series of actions to reduce the quantity of nutrients reaching the lakes from the catchment, due to the weathering action of rainwater and the percolate from stables and manure heaps. To do this it is necessary to control livestock distribution over the pastureland and treat the wastewater derived from the stables properly, uniformly spreading it over the entire pastureland area. Fencing is the most effective way to control grazing distribution (Mosley et al., 1999), but an appropriate water supply strategy can 
also help (Miner et al., 1992). The redistribution of wastewater from stables was traditionally obtained through a channel system with small stone embankments $(15-20 \mathrm{~cm}$ large and 15-20 cm deep) running through the entire pastureland. A complete recovery of this traditional practice would reduce the risk that the percolate reaches the lakes. Another complementary strategy could be to reduce the nutrient content of wastewater through treatment plants. The Gran Paradiso National Park is currently testing the creation of two phytoremediation plants as a method for treating wastewater from mountain farming within the LIFE+ project BIOAQUAE (www.bioaquae.eu) and the program for the development of rural areas of the Piedmont Region (PSR 20072013). Constructed wetlands can improve water quality while promoting biodiversity by the creation of valuable aquatic habitats.

\section{CONCLUSIONS}

The long history of coexistence between transhumance and alpine wildlife does not protect natural ecosystems from some damage produced by livestock grazing. Our study quantified the effects of livestock on the water quality of twenty alpine lakes, in the Gran Paradiso National Park region where transhumance is an ancient practice. We selected lakes with no, soft and heavy impact of transhumance and we found that the livestock impact followed a general coherent scheme affecting water transparency, nutrient concentration and bacterial abundance only in heavy-impacted lakes. From our study we concluded that transhumance can locally increase the trophic state of alpine lakes, with possible bottom-up indirect ecological effects. Alpine lakes can sustain only a soft level of livestock grazing without showing significant ecological changes. It is necessary to maintain soft levels of transhumance in respect of natural resources, sustaining at the same time the unstable ecosystems created by livestock grazing. There are many conservation measures, including fencing, water supply and livestock exclosure, that can be undertaken to reduce the ecological impact of transhumance. Some of them require the recovery of ancient pastoral practices and others the use of innovative bioengineering techniques.

\section{ACKNOWLEDGEMENTS}

We thank Bruno Bassano, Giuseppe Bogliani, Achaz von Hardenberg, Aldo Marchetto, Giuseppe Morabito and many students and field assistants who made this research possible, and the Park wardens for their hospitality. Funding and logistic support for this research were provided by the Gran Paradiso National Park within the framework of the FP7 ACQWA Project (Assessment of Climatic Change and Impacts on the Quantity and Quality of Water, Grant agreement no. 212250) and the LIFE+ project BIOAQUAE (Biodiversity Improvement of Aquatic Alpine Ecosystems).

\section{REFERENCES}

APAT, Irsa-Cnr, 2003. Metodi analitici per le acque, Manuali e linee guida, 29, Roma, Italy.

APHA, AWWA, WEF, 2005. Standard Methods for the examination of water and wastewater (Method 4110 B), American Public Healt Association, Washington DC, 1325 p.

Belsky A.J., Matzke A. and Uselman S., 1999. Survey of livestock influences on stream and riparian ecosystems in the western United States. J Soil Water Conserv., 54, 419-431.

Bergstrom A.K., 2010. The use of TN:TP and DIN:TP ratios as indicators for phytoplankton nutrient limitation in oligotrophic lakes affected by $\mathrm{N}$ deposition. Aquat. Sci., 72, 277-281.

Bunce R.G.H., Pérez-Soba M., Jongman R.H.G., Gómez Sal A., Herzog F. and Austad I., 2004. Transhumance and biodiversity in European mountains, Report of the EU-FP5 project TRANSHUMOUNT, IALE, Wageningen, $321 \mathrm{p}$. 
Callieri C. and Bertoni R., 1999. Organic carbon and microbial food web assemblages in an oligotrophic Alpine lake. J. Limnol., 58, 136-143.

Callieri C., Morabito G., Huot Y., Neale P.J. and Litchman E., 2001. Photosynthetic response of picoand nanoplanktonic algae to UVB, UVA and PAR in a high mountain lake. Aquat. Sci. 63, 286-293.

Camarero L., Rogora M., Mosello R., Anderson N.J., Barbieri A., Botev I., Kernan M., Kopáček J., Korhola A., Lotter A.F., Muri G., Postolache C., Stuchlík E., Thies H. And Wright R.F., 2009. Regionalisation of chemical variability in European mountain lakes. Freshwat. Biol., 54, 2452-2469.

Cernusca A., Tappeiner U. and Bayfield N., 1999. Land-use changes in European mountain ecosystems, Blackwell Wissenschafts-Verlag, Berlin, $368 \mathrm{p}$.

Del Rosario R.B., Betts E.A. and Resh V.H., 2002. Cow manure in headwater streams: tracing aquatic insect responses to organic enrichment. J. N. Am. Benthol. Soc., 21, 278-289.

Derlet R.W. and Carlson J.R., 2004. An analysis of wilderness water in Kings Canyon, Sequoia, and Yosemite National Parks for coliform and pathologic bacteria. Wild. Environ. Med., 15, 238-244.

Derlet R.W. and Carlson J.R., 2006. Coliform bacteria in Sierra Nevada wilderness lakes and streams: what is the impact of backpackers, pack animals, and cattle? Wild. Environ. Med., 17, 15-20.

Derlet R.W., Ger K.A., Richards J.R. and Carlson J.R., 2008. Risk factors for coliform bacteria in backcountry lakes and streams in the Sierra Nevada mountains: a 5-year study. Wild. Environ. Med., 19, 82-90.

Derlet R.W., Goldman C.R. and Connor M.J., 2010. Reducing the impact of summer cattle grazing on water quality in the Sierra Nevada Mountains of California: a proposal. J. Water Health, 15, 347-357.

Derlet R.W., Richards J.R., Tanaka L.L., Hayden C., Ger K.A. and Goldman C.R., 2012. Impact of summer cattle grazing on the Sierra Nevada watershed: aquatic algae and bacteria. J. Environ. Publ. Health, 2012, ID760108.

Farquhar F.P., 1965. History of the Sierra Nevada, University of California Press, Berkeley, 278 p.

Fleischner T.L., 1994. Ecological costs of livestock grazing in western North America. Conserv. Biol., 8, 629-644.

Fraser I. and Chisholm T., 2000. Conservation or cultural heritage? Cattle grazing in the Victoria Alpine National Park. Ecol. Econ., 33, 63-75.

Fresenius W., Quentin K.E. and W. Schneider W., 1988. Water Analysis. Springer-Verlag, Berlin, 804 p.

Hadfield J.D., 2010. MCMC methods for multi-response generalized linear mixed models: the MCMCglmm R Package. J. Stat. Soft., 33, 1-22.

Hansson L.A., 1992. Factors regulating periphytic algal biomass. Limnol. Oceanogr., 37, 322-328.

Hausmann S., Lotter A.F., Van Leeuwen J.F.N., Ohlendorf C., Lemcke G., Grönlund E. and Sturm M., 2002. Interactions of climate and land use documented in the varved sediments of Seebergsee in the Swiss Alps. The Holocene, 12, 279-289.

Herzog F., Bunce R.G., Pérez-Soba M., Jongman R.H., Sal A.G. and Austad I., 2005. Policy Options to Support Transhumance and Biodiversity in European Mountains: A Report on the TRANSHUMOUNT Stakeholder Workshop. Landquart/Zurich, Switzerland, 26-28 May 2004. Mt. Res. Dev., 25, 82-84.

Hinder B., Baur I., Hanselmann K. and Schanz F., 1999. Microbial food web in an oligotrophic high mountain lake (Jöri lake III, Switzerland). J. Limnol., 58, 162-168.

Klein D.R., 1987. Vegetation recovery patterns following overgrazing by reindeer on St. Matthew Island. J. Range Manage., 40, 336-338.

Knapp R.A. and Matthews K.R., 1996. Livestock grazing, golden trout, and streams in the Golden Trout Wilderness, California: impacts and management implications. N. Am. J. Fish. Manage., $16,805-820$.

Laiolo P., Dondero F., Ciliento E. and Rolando A., 2004. Consequences of pastoral abandonment for the structure and diversity of the alpine avifauna. J. Appl. Ecol., 41, 294-304.

Lichtenberger E., 1994. Die Alpen in Europa. Österreochiske Academie der Wissenshaften. Veröffentlichungen der Kommision für Humanökologie, 5, 53-86.

Madigan M.T., Martinko J.M., Dunlap P.V. and Clark D.P., 2009. Brock biology of microorganisms, 12th ed. Benjamin-Cummings Publishing Company, Pearson, San Francisco, 1168 p. 
Marchetto A., Mosello R., Psenner R., Barbieri A., Bendetta G., Tait D., Tartari G.A., 1994. Evaluation of the level of acidification and the critical loads for Alpine lakes. Ambio, 23, 150-154.

Miner J.R., Buckhouse J.C. and Moore J.A., 1992. Will a water trough reduce the amount of time hay-fed livestock spend in the stream (and therefore improve water quality)? Rangelands, 14, 35-38.

Mosley J.C., Cook P.S., Griffis A.J. and O'Laughlin J., 1999. Guidelines for managing cattle grazing in riparian areas to protect water quality: review of research and best management practices Policy. Idaho Forest, Wildlife and Range Policy Analysis Group, Moscow, 67 p.

Myers L. and Kane J., 2011. The impact of summer cattle grazing on surface water quality in high elevation mountain meadows. Wat. Qual. Exposure Health, 3, 51-62.

Myers L. and Whited B., 2012. The impact of cattle grazing in high elevation Sierra Nevada mountain meadows over widely variable annual climatic conditions. J. Environ. Protect., 3, 823-837.

Ohio State University, 2006. Ohio Livestock Manure Management Guide. Bulletin 604-06. Ohio State University, Columbus, Ohio.

Ohlendorf C., Bigler C., Goudsmit G.H., Lemcke G., Livingstone D.M., Lotter A.F., Müller B. and Sturm M., 2000. Causes and effects of long periods of ice cover on a remote high Alpine lake. J. Limnol., $59,65-80$.

Powers B., Johnson M.D., LaManna J.A. and Rich A., 2011. The influence of cattle grazing on pocket gophers in the central Sierra Nevada Mountains, California: potential implications for great gray owls. Northwestern Naturalist, 92, 13-18.

Previtali F., 2011. Mountain Anthroscapes, the Case of the Italian Alps. In: Kapur S., Eswaran H. and Blum W.E.H. (eds.), Sustainable Land Management Springer, Berlin Heidelberg, 143-161.

R Development Core Team, 2010. R: A Language and Environment for Statistical Computing. R Foundation for Statistical Computing, Vienna, Austria. http://www.R-project.org/ [1 January 2014].

Rogora M., Mosello R., Arisci S., Brizzio M.C., Barbieri A., Balestrini R., Waldner P., Schmitt M., Stähli M., Thimonier A., Kalina M., Puxbaum H., Nickus U., Ulrich E. and Probst A., 2006. An overview of atmospheric deposition chemistry over the Alps: present status and long-term trends. Hydrobiol., $562,17-40$.

Rolland A., Rimet F. and Jacquet S., 2010. A 2-year survey of phytoplankton in the Marne Reservoir (France): a case study to validate the use of an in situ spectrofluorometer by comparison with algal taxonomy and chlorophyll a measurements. Knowl. Managt. Aquatic Ecosyst., 398, 02.

Sarr D.A., 2002. Riparian livestock exclosure research in the western United States: a critique and some recommendations. Environ. Manage., 30, 516-526

Sheffield R.E., Mostaghimi S., Vaughn D.H., Collins E.R. and Allen V.G., 1997. Off- stream water sources for grazing cattle as a stream bank stabilization and water quality BMP. T. Am. Soc. Agric. Eng., 40, 595-604.

Smith M.A., Rodgers J.D., Dodd J.L. and Skinner Q.D., 1992. Habitat selection by cattle along an ephemeral channel. J. Range Manage., 45, 385-389.

Sommaruga R., 2001. The role of solar UV radiation in the ecology of alpine lakes. J. Photoch. Photobiol. $B, 62,35-42$.

Tiberti R., Metta S., Austoni M., Callieri C., Morabito G., Marchetto A., Rogora M., Tartari G.A., von Hardenberg J. and Provenzale A., 2013. Ecological dynamics of two remote alpine lakes during ice-free season. J. Limnol., 72, e33.

Tiberti R., von Hardenberg A. and Bogliani G., 2014. Ecological impact of introduced fish in high altitude lakes: a case of study from the European Alps. Hydrobiol., 724, 1-19.

Ursem C., Evans C.S., Ger K.A., Richards J.R. and Derlet R.W., 2009. Surface water quality along the central John Muir Trail in the Sierra Nevada Mountains: coliforms and algae. High Altitude Med. Biol., 10, 349-355.

Valderrama J.C., 1981. The simultaneous analysis of total nitrogen and total phosphorus in natural waters. Mar. Chem., 10, 109-122.

Wille A., Sonntag B., Sattler B. and Psenner R., 1999. Abundance, biomass and size structure of the microbial assemblage in the high mountain lake Gossenköllesee (Tyrol, Austria) during the ice-free period. J. Limnol., 58, 117-126. 